\title{
Feeding Choice and the Fate of Organic Materials Consumed by Sesarma Crabs Perisesarma bidens (De Haan) When Offered Different Diets
}

\author{
Islam S. S. Mchenga ${ }^{1,2,3}$ and Makoto Tsuchiya ${ }^{3}$ \\ ${ }^{1}$ The First Vice President's Office, Department of Environment, P.O. Box 2808, Zanzibar, Tanzania \\ ${ }^{2}$ School of Education, Arts and Science, State University of Zanzibar, P.O. Box 147, Zanzibar, Tanzania \\ ${ }^{3}$ Laboratory of Ecology and Systematics, Faculty of Science, University of the Ryukyus, Senbaru 1, Nishihara, Okinawa 903-0213, \\ Japan \\ Correspondence should be addressed to Islam S. S. Mchenga, islamsalum@yahoo.co.uk
}

Received 29 October 2010; Accepted 30 December 2010

Academic Editor: Pei-Yuan Qian

Copyright ( $) 2010$ I. S. S. Mchenga and M. Tsuchiya. This is an open access article distributed under the Creative Commons Attribution License, which permits unrestricted use, distribution, and reproduction in any medium, provided the original work is properly cited.

\begin{abstract}
The feeding preference of the sesarmid crab Perisesarma bidens was investigated when offered different diets: Enteromorpha intestinalis (algae), Kandelia obovata leaves, and propagules. Nutritional value of food, its assimilation, and fates were evaluated using a combination approach of the fatty acids (FAs) and $\mathrm{C} / \mathrm{N}$ ratios. When offered a mixed diet, male crabs preferred algae than leaves and/or propagules, while a female preference was equally for leaves and algae but less than propagules. The nutritional value of algae was higher as indicated by low $\mathrm{C}: \mathrm{N}$ ratios and high $\omega 3 / \omega 6$ ratios than leaves and propagules. FAs comparison of tissues and faeces indicated that crabs efficiently assimilate essential fatty acids (EFAs) from a given diet in the order of algae greater than leaves and propagules. Despite of sesarmid crabs being a mangrove leaf-eater, E. intestinalis can potentially be important source of nitrogen supplement for $P$. bidens under mangrove forests.
\end{abstract}

\section{Introduction}

Sesarmid crabs are the most abundant benthic fauna inhabiting mangrove ecosystems of the Indo-Pacific region $[1,2]$. They play a vital ecological role in the mangrove foodweb as leaf litter processors $[3,4]$. However, they are often viewed as threats to the successful regeneration or restoration of mangrove forests through their predation of propagules $[5,6]$. Sesarmid crabs are also reported to crop on surface sediment feeding on a variety of organic materials $[4,7]$. In addition, some members of the sesarmid crab exhibit sexspecific feeding habits [8].

Leaf-eating mangrove crabs are extremely dependent on the mangrove litter (leaves and propagules). Leaf materials however, are an inadequate diet given that, irrespective of their stage of senescence and decomposition, it contains low nitrogen content. Therefore, leaf-eating crabs must supplement their diet with nitrogen from other resources [9]. These include algae, bacteria, ingestion of their own faeces colonized by macroorganisms, or grazing on surface sediments $[4,7,10]$. Previous studies have suggested that crabs show food selective preferences depending on the food nutritional values, varieties, and accessibility $[11,12]$.

The critical value of $17: 1$ for the $\mathrm{C}: \mathrm{N}$ ratio has often been used as a point of comparison to determine the nutritional value of food resources [13]. Dietary $\mathrm{C}: \mathrm{N}$ ratios above $17: 1$ are considered to be under the nutritional requirement. However, crabs were reported to consume plant litter with $\mathrm{C}: \mathrm{N}$ ratios ranging from $25: 1$ to $183.5: 1[9,14,15]$. Therefore, crab choice in the consumption of mangrove litter is unclear.

As such, discrimination among organic matter sources in marine ecosystems has been carried out using fatty acids (FAs) as biomarkers [16]. Their structural diversity and high 
biological specificity [17] allows fatty acids to be widely used as biomarkers to examine the sources, fate, and transformation of organic matter as well as their contribution to the sediment organic matter pool [12]. In addition, fatty acids are important due to their role in the transfer of carbon and energy through food webs and in regulation of metabolic processes in marine ecosystems [18]. In the present study, a combination of the FAs approach and $\mathrm{C} / \mathrm{N}$ ratios was used to evaluate the nutritional value of crab food resources, the preference of crabs in the consumption of different food types, its assimilation, and fates.

Previously conducted feeding experiments have tested the preference of sesarmid crabs in the consumption of mangrove litter species and types (green, yellow, or brown), $[3,19-21]$. To our knowledge, there is little literature, if any, on sesarmid crabs food choice of other categories within mangrove forests. Therefore, the aim of present study is to investigate the feeding preference of the sesarmid crab Perisesarma bidens on Kandeli obovata leaves, propagules, and Enteromorpha intestinalis (algae). Since P. bidens is primarily mangrove leaf-eater, the null hypothesis is that crabs would have no preference on algae to brown leaf or propagules.

\section{Materials and Methods}

2.1. Collection and Handling of Crabs and Food Materials. All samples were collected from the Sashiki Bay mangrove forest, in the southern part of Okinawa Island, Japan $\left(26^{\circ} \mathrm{N}, 128^{\circ} \mathrm{E}\right)$ in summer 2007. In the Sashiki bay, the mangrove forest is dominated by K. obovata trees in the upper tidal muddy area. The sesarmid crab, $P$. bidens, is abundant under the mangroves and most of their activity restricted to the area within mangrove strand.

K. obovata brown leaves, matured propagules, fresh green macroalgae (Enteromorpha intestinalis), and sesarmid crabs, $P$. bidens, were collected and transported to the laboratory for feeding consumption assays. In the laboratory, leaves and propagules were presoaked in seawater for 24 hours to allow some tannins and other feeding deterrents to leach out. The leached leaves and propagules, together with algae, were then rinsed with distilled water, dried to a constant weight for approximately 48 hours at $80^{\circ} \mathrm{C}$, and weighed. The dried, leached propagules were then placed in filtered seawater for 2 weeks allowed to regain its tenderness before being offered to the crabs.

Sesarmid crabs, $P$. bidens, with a carapace width ranging from $13 \sim 22 \mathrm{~mm}$ and weight of 2.5 to $11.2 \mathrm{~g}$, were acclimated to the aquarium conditions and allowed to empty their gut contents for one week. After the starving period, all crabs were weighed and placed into separate aquariums for feeding assay. In addition, three non-starved crabs were immediately dissected and their pancreatic tissues were used for FAs analysis to determine their food sources under the field conditions.

2.2. Feeding Preference Experiment. Six replicates, with one crab in each aquaria $(28 \times 17 \times 17 \mathrm{~cm})$, were established for both male and female crabs. The aquaria were slightly elevated on one side (about $2 \mathrm{~cm}$ ) to provide a dry refuge for the crabs and were supplied with filtered seawater (salinity $30 \mathrm{ppt}$ at $25^{\circ} \mathrm{C}$ ) to a depth of $2 \mathrm{~cm}$. The seawater was aerated by using an air pump (LUNG GX 700). In the first treatment, crabs were separately offered each type of food (leaf, propagules, or algae) for 3 days. After each treatment, crabs were starved for 5 days to empty their guts before being offered another diet. For the second treatment, crabs were supplied with mixed food types (leaf + propagule, leaf + algae, algae + propagules) for 3 days. Other three aquaria, without crabs, were also established for each food type to provide a control for weight loss due to leaching during the experiments.

All leaf and algae remains were collected after 24 hours and the remains of propagules after 72 hours of feeding treatment. Collected uneaten materials were rinsed briefly with distilled water, dried, weighed, and remeasured to estimate the final weight. Meanwhile, faeces left in the dry area of the aquarium were collected by using forceps, while faeces deposited in the water were retained by filtering the water through preweighed and precombusted $\left(550^{\circ} \mathrm{C}\right) \mathrm{GF} / \mathrm{F}$ filter. All uneaten materials and collected faeces were dried to a constant weight at $80^{\circ} \mathrm{C}$ for 48 hours and weighed. A subsample of faeces collected after crabs were starved for 5 days to empty their guts. The collected faeces were freeze dried and immediately stored at $-40^{\circ} \mathrm{C}$ until fatty acid analysis.

The consumption rate was calculated as the difference between the initial dry weight of the leaf, propagule, or algae and the final dry weight of the uneaten materials. In order to accurately calculate consumption rates, all foodtypes measurements were adjusted for weight loss due to leaching. Consumption rate was expressed in terms of g dry weight of food consumed per $\mathrm{g}$ fresh weight of crab per day. In the case of propagules, the estimation was conducted by dividing 72 hours of consumption rate by 3 . The faecal production rate was calculated as the amount accumulated faeces over 24 hours and expressed as g dry weight per fresh weight of crab per day. Assimilation of food materials was estimated as the difference between consumption and faecal production rates, as follows:

$$
\text { Assimilation efficiency (\% AE) }=\left(\frac{\text { assimilation }}{\text { consumption }}\right) 100 \text {. }
$$

At the end of the feeding experiment, three starved and three nonstarved crabs were dissected and their pancreatic tissues were used for FAs analysis. The amount of collected faeces for a given food type over 3 days were pooled for each individual and used for analysis of FAs and $\mathrm{C} / \mathrm{N}$ ratios. The assimilation of food by crabs was assessed again by comparing the percentage of a particular FA in the crab tissue before (starved) and after feeding experiment (non-starved), and the amount remaining in the faeces of a particular type of food given to the crabs.

2.3. Analytical Methods. Triplicate samples of each dry leaf, propagule, and algae and resulting faeces after the feeding 
TABLE 1: MANOVA results for the effects of processing (before and after gut) and diets (leaves, alagae, and propagule) on composition of nutrients (total carbon and nitrogen contents).

\begin{tabular}{|c|c|c|c|}
\hline & $\mathrm{df}$ & MS & $\mathrm{F}$ \\
\hline & \multicolumn{3}{|c|}{ \%Total carbon } \\
\hline Processing & 1 & 186.8889 & $758.4947^{* * *}$ \\
\hline Diet & 2 & 417.1565 & $1693.043^{* * *}$ \\
\hline processing*Diet & 2 & 40.92527 & $166.0966^{* * *}$ \\
\hline \multirow[t]{2}{*}{ Residual } & 18 & & \\
\hline & \multicolumn{3}{|c|}{ \%Total nitrogen } \\
\hline Processing & 1 & 0.038272 & $1.733518^{\mathrm{NS}}$ \\
\hline Diet & 2 & 1.060039 & $48.01384^{* * *}$ \\
\hline processing*Diet & 2 & 3.666939 & $166.0918^{* * *}$ \\
\hline \multirow[t]{2}{*}{ Residual } & 18 & & \\
\hline & \multicolumn{3}{|c|}{$\mathrm{C} / \mathrm{N}$ ratio } \\
\hline Processing & 1 & 441.5401 & $4.154553^{\mathrm{NS}}$ \\
\hline Diet & 2 & 2288.132 & $21.52956^{* * *}$ \\
\hline processing*Diet & 2 & 3920.505 & $36.88894^{* * *}$ \\
\hline Residual & 18 & & \\
\hline
\end{tabular}

NS = not significant, ${ }^{*} P<.05,{ }^{* *} P<.01,{ }^{* * *} P<.001 ; \mathrm{C} / \mathrm{N}=$ Carbon to nitrogen ratio.

assays were analyzed to determine the total carbon (TOC) and nitrogen (TN) contents. All samples were ground to a fine powder and analysed using a high-sensitivity $\mathrm{C} / \mathrm{N}$ analyser (Shimadzu NC 80).

For lipid extraction, K. obovata brown leaves, propagules and the algae (Enteromorpha intestinalis) thalli were sliced into small pieces and minced by a sterilized mini blender (IB-2). Triplicate samples of leaves, propagules and algae $(\sim 5 \mathrm{~g}$ wet weight), pancreatic tissues $(\sim 0.2-$ $0.3 \mathrm{~g}$ wet weight), and about $0.3 \mathrm{~g}$ dry weight of faeces resulted from a given food were used for lipid analysis. Lipid extraction was conducted following a modified method of Bligh and Dyer [22]. Samples of each category were ultrasonically extracted for 20 minutes with a chloroform:methanol: distilled water mixture $(1: 2: 1$; $20 \mathrm{~cm}^{3}$; v:v:v). Two aqueous-organic layers were formed by the addition of a distilled water:chloroform mixture $\left(1: 1 ; 10 \mathrm{~cm}^{3} ; \mathrm{v}: \mathrm{v}\right)$. The lipids were then transferred into a lower chloroform phase and improved by centrifugation (2000 rpm for 5 minutes). The extracted lipids were filtered through GF/C filter to remove any fine sediments or particulate matter, concentrated by rotary evaporation, and stored in preweighed $4 \mathrm{~mL}$ vials. After evaporating the solvent, the extracts were dried under nitrogen and weighed for total lipid content using an electronic balance with resolution of $0.00001 \mathrm{~g}$ (Sefi IUW-200D SHIMADZU Corporation, Japan). The lipids were then saponified under reflux $\left(2\right.$ hours, $100^{\circ} \mathrm{C}$ ) with a $2 \mathrm{~mol} \mathrm{dm}^{-3} \mathrm{NaOH}$ solution in methanol and distilled water $(2: 1 ; \mathrm{v}: \mathrm{v})$. After acidification with an ultrapure $\mathrm{HCl}$ solution $(37.5 \%), 2 \times 2 \mathrm{~cm}^{3}$ of chloroform were successively added to recover the lipids. The solvent was then evaporated under a nitrogen stream, and FAs were converted to methyl esters under reflux using $1 \mathrm{~mL}$ of $14 \% \mathrm{BF}_{3}$-methanol for 10 minutes. Saponification and methylation were then performed to obtain total FAs [12].

FA methyl esters (FAMEs) were purified using the high performance thin-layer chromatography technique (HPTLC) using Merck (Darmstadt, Germany) plates coated with silica gel. The solvents used for developing were a mixture of hexane: diethyl ether:acetic acid $(70: 30: 1)$. Bands containing FAMEs were scraped and collected in a mixture of chloroform: methanol $(2: 1, \mathrm{v}: \mathrm{v})$ at $40^{\circ} \mathrm{C}$ for 60 minutes. FAMEs were then isolated in the same solution until analysis by gas chromatography. For all samples, a second plate was prepared to estimate the proportion of FAMEs in the total lipids [23]. After drying, the developed plate was scanned using a flatbed scanner (GT-9000; Epson, Tokyo, Japan) and Adobe Photoshop software (version 6.0; San Jose, CA, USA). The resulting image file was imported into NIH image (version 6) to estimate the relative contribution of FAs, as a proportion of total lipids, by integrating the chromatogram [12]).

The fatty acid methyl ester (FAMEs) were separated and quantified by a gas chromatograph (GC 14.B, Shimadzu) equipped with a flame ionization detector. Separation was performed with a free fatty acid phase-(FFAP-) polar capillary column (GL Sciences J0012F11, $30 \mathrm{~m} \times 0.32 \mathrm{~mm}$ internal diameter, $0.25 \mu \mathrm{m}$ film thickness) using helium as a carrier gas $(25 \mathrm{~cm} / \mathrm{sec})$. Samples were injected in the split less mode. After injection at $60^{\circ} \mathrm{C}$, the oven temperature was raised to $150^{\circ} \mathrm{C}$ at a rate of $40^{\circ} \mathrm{C} \mathrm{min}{ }^{-1}$, then to $230^{\circ} \mathrm{C}$ at $3^{\circ} \mathrm{C} \mathrm{min}{ }^{-1}$, and finally held constant for $30 \mathrm{~min}$. The flame ionisation was held at $240^{\circ} \mathrm{C}$. Most FAME peaks were identified by comparison of their retention times to those of authentic standards (Supelco Inc., Bellefonte, PA, USA).

2.4. Statistical Analysis. Difference in the composition of the diets and faeces (before and after the gut) and consumption rates between diets and sexes were compared using multivariate analysis of variance (MANOVA). Diets (three levels), sexes, and processes (two levels) were entered as fixed factors, with total carbon, total nitrogen, $\mathrm{C} / \mathrm{N}$ ratio, assimilation, assimilation efficiency, consumption, and faecal production rates were used as dependent variables. Differences in the concentration of individual or groups of FAs from leaves, propagules, algae, their resulted faeces, starved, and nonstarved tissues for both the field and experimental conditions were tested using a one-way analysis of variance (ANOVA). Post hoc, Student-Newman-Keul's test (S-N-K) was performed to detect differences between treatments when significant differences were found. A two-tailed paired Student's $t$-test was used to compare feeding preferences between diets when crabs offered mixed food types (Leaves+Algae, Leaves+Propagules, and Algae+Propagules). The results were considered significant if $P<.05$.

\section{Results}

3.1. C/N Ratios and FA Profiles of Food Types. Present results revealed both the independent and interactive influence of food types (diets) and processes (before and after gut) on total carbon, nitrogen, and $\mathrm{C} / \mathrm{N}$ ratio (MANOVA 
TABLE 2: Mean percentage contributions of individual, FA classes, and $\omega 3 / \omega 6$ ratio indifferent food types. Values are mean \pm SE $(n=3)$. MUFA: Monounsaturated fatty acid, PUFA, polyunsaturated fatty acid, SAFA: saturated fatty acid, BrFA: Branched fatty acid and LCFAs: long chain fatty acid.

\begin{tabular}{|c|c|c|c|}
\hline & K. obovata (brown leaves) & E. intestinalis (algae) & K. obovata (propagule) \\
\hline $14: 0$ & $2.1 \pm 1.5$ & $0.6 \pm 0.0$ & $1.3 \pm 0.2$ \\
\hline $15: 0$ iso & - & - & - \\
\hline $15: 0$ ant & - & - & - \\
\hline $15: 0$ & $0.4 \pm 0.2$ & $0.6 \pm 0.0$ & - \\
\hline $16: 0$ & $28.3 \pm 3.8$ & $28.5 \pm 2.4$ & $24.3 \pm 0.5$ \\
\hline $16: 1 \omega 9$ & $0.7 \pm 0.3$ & $5.7 \pm 3.7$ & $0.3 \pm 0.3$ \\
\hline $16: 1 \omega 7$ & $0.4 \pm 0.4$ & $0.6 \pm 0.2$ & - \\
\hline $17: 0$ iso & $0.2 \pm 0.3$ & $1.5 \pm 0.5$ & - \\
\hline $17: 0$ ant & - & $0.9 \pm 0.2$ & - \\
\hline $17: 0$ & $1.2 \pm 0.0$ & $0.3 \pm 0.2$ & $0.4 \pm 0.0$ \\
\hline $17: 1$ & $0.2 \pm 0.1$ & $0.8 \pm 0.0$ & - \\
\hline $18: 0$ & $5.0 \pm 0.6$ & $0.5 \pm 0.0$ & $2.2 \pm 0.1$ \\
\hline $18: 1 \omega 9$ & $5.2 \pm 1.0$ & $9.0 \pm 0.2$ & $4.7 \pm 0.2$ \\
\hline $18: 1 \omega 7$ & $1.8 \pm 1.0$ & - & - \\
\hline $18: 2 \omega 6$ & $19.5 \pm 4.9$ & $9.6 \pm 0.3$ & $41.1 \pm 1.2$ \\
\hline $18: 3 \omega 6$ & $0.3 \pm 0.4$ & $1.4 \pm 0.0$ & - \\
\hline $18: 3 \omega 4$ & - & - & - \\
\hline $18: 3 \omega 3$ & $22.1 \pm 1.7$ & $23.1 \pm 0.6$ & $10.7 \pm 0.5$ \\
\hline $18: 4 \omega 3$ & $0.7 \pm 0.7$ & $1.3 \pm 1.8$ & - \\
\hline $20: 0$ & $0.6 \pm 0.2$ & - & $0.3 \pm 0.1$ \\
\hline $20: 1 \omega 9$ & - & - & - \\
\hline $20: 1 \omega 7$ & - & - & - \\
\hline $20: 2$ & - & - & $1.1 \pm 0.1$ \\
\hline $20: 3 \omega 6$ & - & $0.4 \pm 0.5$ & - \\
\hline $20: 4 \omega 6$ & $0.3 \pm 0.4$ & $0.8 \pm 0.5$ & - \\
\hline $20: 3 \omega 3$ & - & - & - \\
\hline $20: 4 \omega 3$ & - & $0.5 \pm 0.0$ & - \\
\hline $20: 5 \omega 3$ & $0.3 \pm 0.2$ & $0.8 \pm 0.0$ & - \\
\hline $22: 0$ & $1.0 \pm 1.1$ & $0.7 \pm 0.1$ & $0.3 \pm 0.0$ \\
\hline $22: 6 \omega 3$ & $0.8 \pm 1.1$ & - & - \\
\hline $24: 0$ & $1.0 \pm 0.2$ & $1.5 \pm 0.0$ & $0.8 \pm 0.2$ \\
\hline $26: 0$ & $1.3 \pm 1.2$ & - & $4.4 \pm 1.0$ \\
\hline $28: 0$ & $0.2 \pm 0.3$ & - & $4.0 \pm 1.1$ \\
\hline $30: 0$ & - & - & $0.3 \pm 0.1$ \\
\hline $32: 0$ & $1.6 \pm 0.4$ & - & $0.9 \pm 0.3$ \\
\hline$* \Sigma \mathrm{MUFA}$ & $8.9 \pm 0.3$ & $16.4 \pm 3.6$ & $5.5 \pm 0.1$ \\
\hline$* \Sigma$ PUFA & $44.1 \pm 3.1$ & $38.4 \pm 2.3$ & $53.0 \pm 1.8$ \\
\hline$* \Sigma$ SAFA & $42.5 \pm 2.8$ & $33.5 \pm 2.2$ & $31.3 \pm 0.4$ \\
\hline$* \Sigma \mathrm{BrFA}$ & $1.2 \pm 0.8$ & $9.5 \pm 0.9$ & $0.5 \pm 0.2$ \\
\hline$* \Sigma$ LCFA & $3.1 \pm 1.0$ & - & $9.7 \pm 2.4$ \\
\hline Unidentified & $0.2 \pm 0.2$ & $2.3 \pm 1.6$ & $0.1 \pm 0.1$ \\
\hline Total & 100 & 100 & 100 \\
\hline $\mathrm{n} 3 / \mathrm{n} 6$ ratio & $1.3 \pm 0.4$ & $2.2 \pm 0.2$ & $0.3 \pm 0.0$ \\
\hline
\end{tabular}

*Includes fatty acids not indicated in this table; -not detected or traces.

results Table 1). There was a significant difference in total carbon and nitrogen contents between food types, with higher content of total carbon in propagules and brown leaves of $K$. obovata $\left(47.6 \pm 0\right.$ and $46.8 \pm 0.3 \mathrm{mg} \mathrm{g}^{-1}$, resp.) than
E. intestinalis $\left(33.6 \pm 0.1 \mathrm{mg} \mathrm{g}^{-1}\right)$. On the contrary, the highest nitrogen content measured in the algae $\left(2.4 \pm 0.2 \mathrm{mg} \mathrm{g}^{-1}\right)$ followed by the brown leaves and the propagules $(1.0 \pm 0.1$ and $0.8 \pm 0.0 \mathrm{mg} \mathrm{g}^{-1}$, resp., S-N-K multiple comparison on 
TABLE 3: MANOVA results for the effects of diets (leaves, alagae, and propagule) and sexes (male and female) on consumption faecal production, assimilation rates, and assimilation efficiency.

\begin{tabular}{|c|c|c|c|}
\hline & $\mathrm{df}$ & MS & $\mathrm{F}$ \\
\hline & \multicolumn{3}{|c|}{ Assimilation rate (in $\mathrm{g} \mathrm{crab}^{-1} \mathrm{day}^{-1}$ ) } \\
\hline 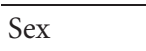 & 1 & 0.000254 & $0.4267^{\mathrm{NS}}$ \\
\hline Diet & 2 & 0.011423 & $19.1524^{* * *}$ \\
\hline Sex*Diets & 2 & 0.000384 & $0.64462^{\mathrm{NS}}$ \\
\hline \multirow[t]{2}{*}{ Residue } & 36 & & \\
\hline & \multicolumn{3}{|c|}{ Assimilation Efficiency (in \%) } \\
\hline Sex & 1 & 194.2444 & $0.360282^{\mathrm{NS}}$ \\
\hline Diet & 2 & 4621.282 & $8.571506^{* *}$ \\
\hline Sex*Diets & 2 & 778.8804 & $1.444659^{\mathrm{NS}}$ \\
\hline \multicolumn{4}{|l|}{ Residue } \\
\hline & \multicolumn{3}{|c|}{ Consumption rate (in $\left.\mathrm{g} \mathrm{crab}^{-1} \mathrm{day}^{-1}\right)$} \\
\hline Sex & 1 & 0.000409 & $0.424249^{\mathrm{NS}}$ \\
\hline Diet & 2 & 0.013668 & $14.16279^{\mathrm{NS}}$ \\
\hline Sex*Diets & 2 & 0.000182 & $0.188508^{\mathrm{NS}}$ \\
\hline \multirow[t]{2}{*}{ Residue } & 36 & & \\
\hline & \multicolumn{3}{|c|}{ Faecal production (in $\mathrm{g} \mathrm{crab}^{-1} \mathrm{day}^{-1}$ ) } \\
\hline Sex & 1 & $1.83 \mathrm{E}-05$ & $0.23731^{\mathrm{NS}}$ \\
\hline Diet & 2 & 0.000108 & $1.397996^{* * *}$ \\
\hline Sex*Diets & 2 & $6.1 \mathrm{E}-05$ & $0.789862^{\mathrm{NS}}$ \\
\hline Residue & 36 & & \\
\hline
\end{tabular}

NS = not significant, ${ }^{*} P<.05, * * P<.01, * * * P<.001$.

diets, $P<.05)$. Therefore, algae had the lowest $\mathrm{C} / \mathrm{N}$ ratios among the food types offered during the experiment.

The percentages of the FA profiles significantly differed between the food types. A comparison of the FA class compositions showed that $K$. obovata brown leaves had the highest amount of saturated FAs (SAFAs) (Table 2), but the major SAFA, 16:0 did not differ between diets. The most abundant FA class in all food types were the polyansaturated FAs (PUFAs) contributing between 38 and 52\%; however, no significant differences was found between algae and leaves. In contrast, the propagules contained the highest

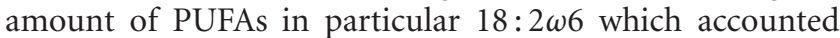
for $42 \%$ of the total FAMEs (S-N-K, $P<.05$ ). The other abundant individual PUFA in algae and leaves was 18:3 103 (23 and 22\%, resp.) with the lowest concentration measured in propagules $(8.6 \%)$. The difference in the essential FAs (EFAs) linoleic $(\omega 6)$ and linolenic families $(\omega 3)$, between leaves, algae, and propagules resulted in significantly larger $\omega 3 / \omega 6$ ratios in algae $(2.2 \%)$ than leaves and propagules (1.3 and 0.2, resp., ANOVA, $F=30.2 . \mathrm{df}=2,6 ; P<.001$ ). The EFA $20: 5 \omega 3$ was found in relatively small amounts in leaves $(0.3 \%)$ than in propagules $(0.5 \%)$ and algae $(0.8 \%)$, while the FA, 22:6w3 was only detected in leaves $(0.8 \%)$. Monounsaturated FAs accounted for a considerably higher percentage in algae than leaves and propagules, in particular the percentage contribution of $18: 1 \omega 9$ and 16:1 19 (9 and $5.7 \%$, resp.), while the FA $18: 1 \omega 7$ was only detected in leaves and propagules. Generally, branched FAs (BrFAs) were significantly higher in algae; however, the sum of bacterial FA markers which includes odd-branched FAs $(15: 0-17: 0$ iso, anteiso) and the MUFA, 18:1 $1 \omega 7$ did not differ between food types. In contrast, the sum of the fungal FAs $(18: 2 \omega 6$ and $18: 1 \omega 9)$ was significantly higher in leaves and propagules (24.7 and $46.3 \%$, resp.). The long chain FAs (LCFAs) were measured in considerable smaller amounts in leaves and propagules $(\sim 3 \%)$ and was not detected in algae.

3.2. Consumption and Defaecation Rates and Assimilation Efficiency. Under the laboratory feeding conditions, P. bidens showed no distinction between $K$. obovata brown leaves and algae when offered a single diet; however, a considerable lower consumption rate was observed for propagules (MANOVA, Table 3). The consumption rates of leaves and algae for male and female crabs were similar with the exception of propagules where males consumed a significantly higher amount than female crabs $(t$-test, $t=4.2, \mathrm{df}=5$; $P<.01)$. When offered a mixed diet of leaves + algae, males exhibited a significantly higher preference for algae than leaves (12.9 and $5.7 \mathrm{mg} \mathrm{g}$ [crab fresh $\mathrm{wt}]^{-1} \mathrm{~d}^{-1}$, resp.; $t$-test, $t=-3.1, \mathrm{df}=5 ; P<.02)$; however, the female consumption rate was similar for leaves and algae $(9.3$ and $6.6 \mathrm{mgg}$ [crab fresh $w t]^{-1} d^{-1}$, resp.) (Figure 1(a)). Both male and female crabs showed significantly higher consumption rates of leaves and algae than propagules when offered mixed diets of leaf + propagules or algae + propagules (Figures 1(b) and $1(\mathrm{c}))$. The resulting faecal materials from different food types were correlated with the amount of food consumed by crabs, with the exception of female crabs where less feaces were produced when offered algae. However, overall faecal production rates showed no significant differences between sexes (Table 3 ).

The assimilation efficiency (AE) of $P$. bidens on propagules was significantly lower (MANOVA, S-N-K multiple comparison on AE, $P<.01$ ) and accounted for 46 and $48 \%$ in male and female crabs, respectively. Male crabs exhibited a higher assimilation efficiency for leaves than algae (89.7 and $78.4 \%$, resp.) while females were observed to have the opposite manner (77 and $84.1 \%$, resp.), but no significant difference was found between sexes (Table 3 ).

3.3. The Fate of Carbon, Nitrogen, and Fatty Acids. The composition of faeces when crabs fed on propagules had a significantly low carbon and higher nitrogen content (35.5 \pm 0.2 and $\left.2.2 \pm 0.2 \mathrm{mg} \mathrm{g}^{-1}\right)$ than fresh propagules $(46.7 \pm 0.8$ and $0.8 \pm 0.0 \mathrm{mg} \mathrm{g}^{-1}$, resp.). When crabs were offered leaves, the resulting faeces had significantly lower nitrogen content $\left(0.7 \pm 0.0 \mathrm{mg} \mathrm{g}^{-1}\right)$, but no different was found in the carbon contents. In contrast, crab faeces contained a significantly lower carbon and nitrogen content when fed on algae (26.4 \pm 0.5 and $0.9 \pm 0.0 \mathrm{mg} \mathrm{g}^{-1}$, resp., MANOVA, S-N-K multiple comparison on diets before and after gut, $P<.0001)$. These results indicate that $P$. bidens had significantly high intake of both nitrogen and carbon from algae, nitrogen but not carbon from brown leaves, and only carbon from propagules.

The profiles of non-starved tissues revealed similar FA compositions when crabs were fed in the laboratory or under field conditions (Table 4). During the laboratory feeding experiments, $P$. bidens significantly assimilated high amounts 


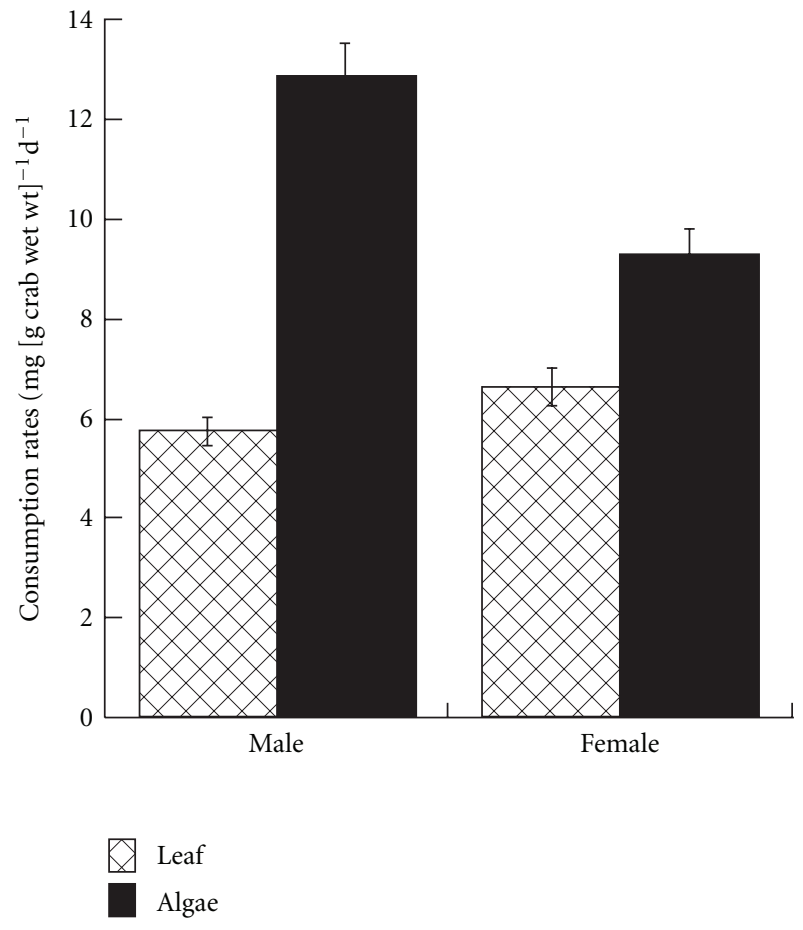

(a) Leaf + Algae

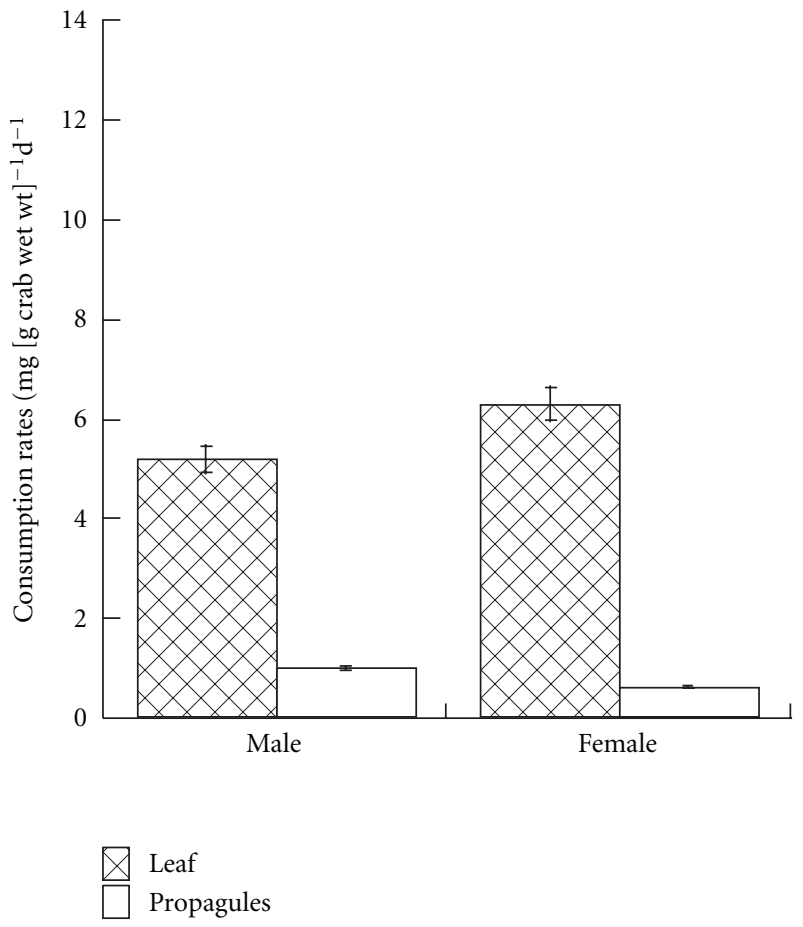

(b) Leaf + Propagules

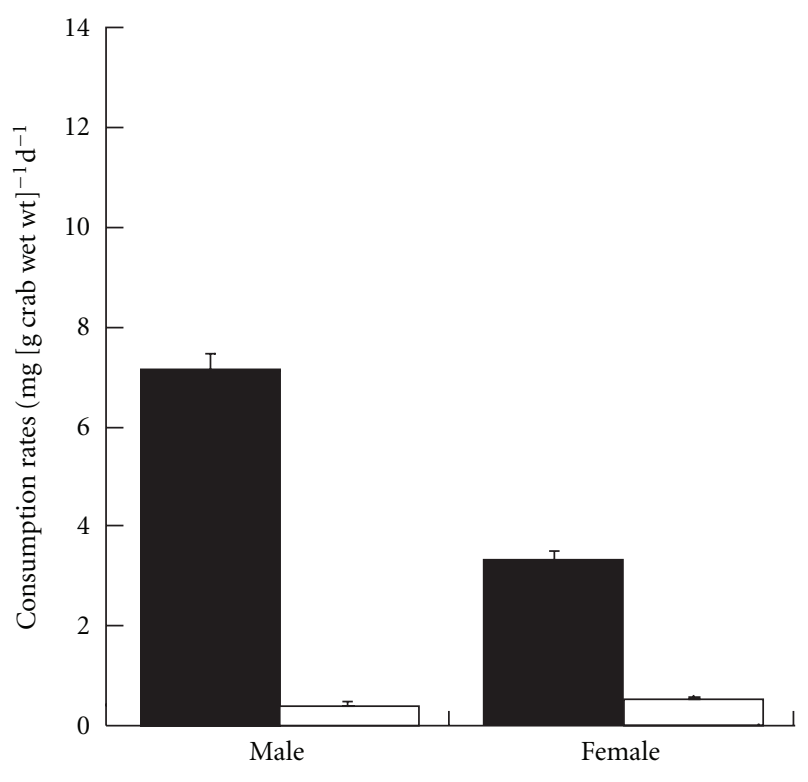

Algae

Propagules

(c) Algae + Propagules

Figure 1: Consumption rates of $P$. bidens offered a mixed diet. Values are mean $\pm \operatorname{SE} n=6$.

PUFAs (38.8\%, ANOVA, $F=67.3 \mathrm{df}=2,15 ; P<.01)$ as compared to the crabs from the mangrove forest (27.7\%). On the contrary, crabs in the field assimilated relatively higher amounts of SAFAs (40.2\%) than under laboratory condition (33.1\%); however, no significant difference was found in MUFAs. Under field and laboratory conditions, crabs assimilated considerably lower amounts of BrFAs and LCFAs $(<2.5 \%)$. 
TABLE 4: Mean percentage contribution of individual and FA classes in crab tissues. Values are means \pm SE $(n=3)$. Sample abbreviations as in Table 2.

\begin{tabular}{|c|c|c|c|}
\hline & $\begin{array}{l}\text { Non-starved tissues } \\
\text { (Exp.) }\end{array}$ & $\begin{array}{c}\text { Nonstarved tissues } \\
\text { (field) }\end{array}$ & $\begin{array}{l}\text { Starved } \\
\text { tissues }\end{array}$ \\
\hline $14: 0$ & $0.9 \pm 0.0$ & $1.9 \pm 0.1$ & $1.8 \pm 0.1$ \\
\hline $15: 0$ iso & - & $0.6 \pm 0.0$ & $0.6 \pm 0.0$ \\
\hline $15: 0$ ant & - & $0.2 \pm 0.0$ & - \\
\hline $15: 0$ & $1.6 \pm 0.0$ & $2.6 \pm 0.1$ & $1.6 \pm 0.0$ \\
\hline $15: 1$ & - & $0.4 \pm 0.1$ & $0.3 \pm 0.0$ \\
\hline $16: 0$ & $17.4 \pm 0.2$ & $18.0 \pm 3.1$ & $19.4 \pm 0.4$ \\
\hline $16: 1 \omega 9$ & $5.7 \pm 0.1$ & $5.9 \pm 1.8$ & $5.9 \pm 0.3$ \\
\hline $16: 1 \omega 7$ & - & $3.8 \pm 2.4$ & $0.2 \pm 0.0$ \\
\hline $17: 0$ iso & $0.3 \pm 0.0$ & $0.5 \pm 0.0$ & $0.5 \pm 0.0$ \\
\hline $17: 0$ ant & - & $0.4 \pm 0.1$ & $0.4 \pm 0.0$ \\
\hline $17: 0$ & $1.9 \pm 0.9$ & $5.3 \pm 0.3$ & $1.3 \pm 0.0$ \\
\hline $17: 1$ & $1.7 \pm 0.1$ & $2.0 \pm 0.3$ & $1.7 \pm 0.1$ \\
\hline $18: 0$ & $7.3 \pm 0.2$ & $7.6 \pm 1.0$ & $7.3 \pm 0.6$ \\
\hline $18: 1 \omega 9$ & $15.3 \pm 0.1$ & $11.9 \pm 4.1$ & $15.3 \pm 0.4$ \\
\hline $18 ; 1 \omega 7$ & $3.8 \pm 0.1$ & $4.4 \pm 3.4$ & $2.4 \pm 0.2$ \\
\hline $18: 2 \omega 6$ & $10.9 \pm 0.2$ & $11.9 \pm 1.1$ & $10.0 \pm 0.1$ \\
\hline $18: 3 \omega 6$ & $0.6 \pm 0.0$ & - & $0.9 \pm 0.0$ \\
\hline $18: 3 \omega 4$ & $0.8 \pm 0.0$ & $1.1 \pm 0.0$ & $1.0 \pm 0.0$ \\
\hline $18: 3 \omega 3$ & $7.3 \pm 0.1$ & $9.5 \pm 0.5$ & $5.5 \pm 0.1$ \\
\hline $18: 4 \omega 3$ & - & - & - \\
\hline $20: 0$ & $1.0 \pm 0.0$ & $1.1 \pm 0.0$ & $1.0 \pm 0.0$ \\
\hline $20: 1 \omega 9$ & $0.5 \pm 0.2$ & $0.6 \pm 0.1$ & $0.5 \pm 0.0$ \\
\hline $20: 1 \omega 7$ & $0.2 \pm 0.2$ & - & $0.3 \pm 0.0$ \\
\hline $20: 2$ & $1.3 \pm 0.0$ & $0.4 \pm 0.0$ & $0.8 \pm 0.0$ \\
\hline $20: 3 \omega 6$ & $0.4 \pm 0.0$ & $0.7 \pm 0.1$ & $0.2 \pm 0.1$ \\
\hline $20: 4 \omega 6$ & $6.8 \pm 0.1$ & $1.4 \pm 0.2$ & $8.6 \pm 0.2$ \\
\hline $20: 3 \omega 3$ & $0.7 \pm 0.0$ & - & $0.4 \pm 0.0$ \\
\hline $20: 5 \omega 3$ & $6.1 \pm 0.1$ & $1.7 \pm 0.2$ & $4.3 \pm 0.1$ \\
\hline $22: 0$ & $1.0 \pm 0.0$ & $1.2 \pm 0.2$ & $0.7 \pm 0.0$ \\
\hline $22: 6 \omega 3$ & $2.2 \pm 0.0$ & $0.8 \pm 0.3$ & - \\
\hline $24: 0$ & $0.6 \pm 0.0$ & $0.9 \pm 0.2$ & $1.7 \pm 0.0$ \\
\hline $26: 0$ & - & - & - \\
\hline $28: 0$ & - & - & - \\
\hline $30: 0$ & $0.3 \pm 0.0$ & $0.3 \pm 0.1$ & - \\
\hline $32: 0$ & - & - & - \\
\hline$* \Sigma \mathrm{MUFA}$ & $27.3 \pm 0.3$ & $29.0 \pm 2.4$ & $26.8 \pm 0.6$ \\
\hline$* \Sigma \mathrm{PUFA}$ & $38.8 \pm 1.2$ & $27.7 \pm 1.5$ & $33.5 \pm 0.3$ \\
\hline$* \Sigma$ SAFA & $33.1 \pm 1.3$ & $40.2 \pm 2.6$ & $36.3 \pm 0.5$ \\
\hline$* \Sigma \mathrm{BrFA}$ & $0.4 \pm 0.1$ & $2.5 \pm 0.2$ & $3.3 \pm 0.4$ \\
\hline$* \Sigma$ LCFA & $0.3 \pm 0.0$ & $0.4 \pm 0.1$ & - \\
\hline Unidentified & - & $0.3 \pm 0.2$ & 0 \\
\hline Total & 100 & 100 & 100 \\
\hline
\end{tabular}

* Includes fatty acids not indicated in this table; -not detected or traces.

Comparisons of individual FAs in starved and nonstarved tissues showed no significant differences in the major
SAFAs, 16:0 and 18:0 which accounted for 17.4\%-19.4\% and $7.3 \%-7.6 \%$, respectively, and the second dominant class MUFAs, $18: 1 \omega 9$ and 18: $1 \omega 7$ contributed $11.9 \%-15.3 \%$ and $2.4 \%-4.4 \%$, respectively. However, the concentration of PUFAs $18: 3 \omega 3,20: 5 \omega 3$, and $22: 6 \omega 3$ were significantly higher in non-starved tissues $(7.3,6.1$, and $2.2 \%$, resp.) than in starved tissues $(5.5,4.3$, and $0 \%$, resp.), in particular for crabs fed under laboratory conditions. A relatively high percentage contribution of bacterial FA markers (the summation of $18: 1 \omega 7$ and odd-branched $15: 0-17: 0$ iso and anteiso) were detected in non-starved (4.2\%-6.2\%) than starved tissues (3.9\%); however, there was no significant difference between tissues types.

FAs profiles of the resulting faeces demonstrated a clear difference when crabs were offered different food types (Table 5). The most abundant SAFA, 16:0, was significantly higher in faeces when crabs were fed on algae (48\%) than leaves and propagules (27 and 19.4\% resp., ANOVA, S-N-K,

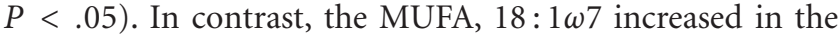
resulting faeces from propagules and algae (18.7 and 11.8, resp.), but significantly decreased when crabs were offered leaves $(2.3 \%, \mathrm{~S}-\mathrm{N}-\mathrm{K}, P<.05)$. The MUFA 18: $1 \omega 9$, however, was low in faeces of the algae $(1.8 \%)$ and moderately increased in faeces of the leaves $(6.7 \%)$ and propagules

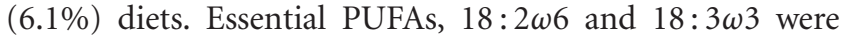
significantly low in faeces when crabs fed on algae than leaves and propagules. Other PUFAs, $20: 4 \omega 6,20: 5 \omega 3$, and $22: 6 \omega 3$ were traced or not detected in faeces regardless of the food type given to the crabs.

Different food types resulted in significant difference in FA class compositions between faeces types. SAFAs were significantly higher in faeces when a crab fed on algae $(60.6 \%)$ than leaves $(50.9 \%)$ and propagules $(36.2 \%)$. In addition, there was a gradual decrease in amounts of PUFAs (5.6\%) when crabs were offered algae, compared to leaves $(14.3 \%)$ and propagules $(12.5 \%)$. Thus $P$. bidens assimilates higher percentage of PUFAs relative to SAFAs when fed on algae than other food types. The amounts of MUFAs were significantly lower $(15.2 \%)$ in the resulting faeces from leaves than algae and propagules (29 and 34.6\%, resp.). A similar pattern was found for bacterial FA markers (sum of $18: 1 \omega 7$ and odd-branched 15:0-17:0 iso and anteiso) which indicates that crabs assimilate bacteria from leaves. In contrast, crabs did not assimilate LCFAs as shown by increased amounts of these FAs in faeces of both propagules and leaves (12.6 and $10.1 \%$ resp.).

\section{Discussion}

Previous studies on sesarmid crab consumption of mangrove litter has suggested that mangrove leaves are not sufficient to fulfill the nitrogen requirements of crabs. Thus, sesarmid crabs have to supplement their diet with nitrogen from other sources such as algae from mangrove roots and trunks $[4,7,9,10]$. Unlike most of the previous studies which investigated crab food choice based on variation in leaf types and species [3, 19-21], the preference of $P$. bidens on algae $E$. intestinalis over $K$. obovata leaves and propagules was tested in this study. Due to a lower 
TABLE 5: Mean percentage contribution of individual and FA classes and bacteria markers of the resulting faecal material. Values are means \pm SE $(n=3)$. Sample abbreviations as in Table 2 .

\begin{tabular}{|c|c|c|c|}
\hline & Leaf faeces & Algae faeces & Propagule faeces \\
\hline $14: 0$ & $3.9 \pm 0.5$ & $1.9 \pm 0.1$ & $1.5 \pm 0.8$ \\
\hline $15: 0$ iso & $0.4 \pm 0.1$ & $1.3 \pm 0.1$ & $1.1 \pm 0.6$ \\
\hline $15: 0$ ant & $0.6 \pm 0.2$ & $0.3 \pm 0.0$ & $1.3 \pm 1.6$ \\
\hline $15: 0$ & $0.9 \pm 0.4$ & $2.0 \pm 0.1$ & $1.2 \pm 0.5$ \\
\hline $15: 1$ & $1.1 \pm 0.5$ & $0.4 \pm 0.1$ & $0.5 \pm 0.2$ \\
\hline $16: 0$ & $27.0 \pm 2.5$ & $48.8 \pm 6.6$ & $19.4 \pm 2.1$ \\
\hline $16: 1 \omega 9$ & $0.9 \pm 0.4$ & $8.6 \pm 1.9$ & $0.4 \pm 0.1$ \\
\hline $16: 1 \omega 7$ & $2.1 \pm 0.4$ & $4.5 \pm 3.0$ & $7.5 \pm 1.2$ \\
\hline $17: 0$ iso & $0.4 \pm 0.1$ & $1.4 \pm 0.2$ & $0.4 \pm 0.0$ \\
\hline $17: 0$ ant & - & - & - \\
\hline $17: 0$ & $1.0 \pm 0.4$ & $0.6 \pm 0.1$ & $1.0 \pm 0.0$ \\
\hline $17: 1$ & $0.6 \pm 0.4$ & $0.8 \pm 0.2$ & $0.9 \pm 0.1$ \\
\hline $18: 0$ & $6.7 \pm 0.8$ & $2.2 \pm 0.1$ & $4.7 \pm 0.3$ \\
\hline $18: 1 \omega 9$ & $6.8 \pm 0.9$ & $1.8 \pm 1.1$ & $6.1 \pm 0.3$ \\
\hline $18: 1 \omega 7$ & $2.3 \pm 1.0$ & $11.8 \pm 1.3$ & $18.7 \pm 0.8$ \\
\hline $18: 2 \omega 6$ & $7.2 \pm 0.1$ & $2.8 \pm 0.2$ & $7.3 \pm 0.2$ \\
\hline $18: 3 \omega 6$ & $0.5 \pm 0.5$ & - & $0.2 \pm 0.1$ \\
\hline $18: 3 \omega 4$ & - & - & - \\
\hline $18: 3 \omega 3$ & $2.8 \pm 0.1$ & $2.0 \pm 0.0$ & $1.9 \pm 0.1$ \\
\hline $18: 4 \omega 3$ & $1.0 \pm 0.8$ & $0.2 \pm 0.1$ & - \\
\hline $20: 0$ & $0.7 \pm 0.1$ & $0.4 \pm 0.0$ & $0.9 \pm 0.1$ \\
\hline $20: 1 \omega 9$ & $0.2 \pm 0.2$ & $0.4 \pm 0.0$ & $0.4 \pm 0.1$ \\
\hline $20: 1 \omega 7$ & $0.1 \pm 0.2$ & $0.3 \pm 0.2$ & - \\
\hline $20: 2$ & $0.4 \pm 0.2$ & - & $0.4 \pm 0.1$ \\
\hline $20: 3 \omega 6$ & - & - & $0.7 \pm 0.1$ \\
\hline $20: 4 \omega 6$ & - & $0.2 \pm 0.1$ & - \\
\hline $20: 3 \omega 3$ & - & - & - \\
\hline $20: 4 \omega 3$ & - & - & $0.7 \pm 0.1$ \\
\hline $20: 5 \omega 3$ & - & - & - \\
\hline $22: 0$ & $0.4 \pm 0.1$ & $0.8 \pm 0.1$ & $1.3 \pm 0.3$ \\
\hline $22: 6 \omega 3$ & - & - & $0.4 \pm 0.0$ \\
\hline $24: 0$ & $1.4 \pm 0.3$ & $0.3 \pm 0.2$ & $2.0 \pm 0.5$ \\
\hline $26: 0$ & $2.0 \pm 0.7$ & - & $6.0 \pm 1.6$ \\
\hline $28: 0$ & $2.7 \pm 1.3$ & - & $5.2 \pm 1.5$ \\
\hline $30: 0$ & $1.1 \pm 0.3$ & - & $0.2 \pm 0.2$ \\
\hline $32: 0$ & $4.3 \pm 1.2$ & $0.4 \pm 0.1$ & $1.3 \pm 0.3$ \\
\hline$* \Sigma \mathrm{MUFA}$ & $15.2 \pm 0.7$ & $29.0 \pm 5.1$ & $34.6 \pm 1.3$ \\
\hline$* \Sigma$ PUFA & $14.3 \pm 2.8$ & $5.6 \pm 0.4$ & $12.5 \pm 0.8$ \\
\hline$* \Sigma$ SAFA & $50.9 \pm 6.2$ & $60.6 \pm 5.7$ & $36.2 \pm 1.7$ \\
\hline$* \Sigma \mathrm{BrFA}$ & $4.0 \pm 1.2$ & $3.3 \pm 0.1$ & $3.2 \pm 1.1$ \\
\hline$* \Sigma$ LCFA & $10.1 \pm 3.0$ & $0.4 \pm 0.1$ & $12.6 \pm 3.6$ \\
\hline Unidentified & $5.5 \pm 3.2$ & $1.1 \pm 0.8$ & $0.9 \pm 0.2$ \\
\hline Total & 100 & 100 & 100 \\
\hline Bacteria & $3.7 \pm 1.1$ & $14.8 \pm 1.3$ & $21.5 \pm 0.8$ \\
\hline
\end{tabular}

*Includes fatty acids not indicated in this table; -not detected or traces.

$\mathrm{C} / \mathrm{N}$ ratio, E. intestinalis could have a higher nutritional value than leaves and propagules whose $\mathrm{C} / \mathrm{N}$ ratios reached above the 17:1 maximum suggested by Russell-Hunter [13]. However, $P$. bidens has no distinct preference between algae and brown leaves than do for propagules when these foods were offered separately. A possible explanation is that brown leaves (partially decompose) could increase in nutritional quality via fungal and bacterial colonization which improves palatability and increases nitrogen contents $[19,24]$. This idea is strongly supported by the presence of a relatively high amount of fungal FAs (sum of $18: 2 \omega 6$ and $18: 1 \omega 9$ ) and bacterial FA markers to some degree (sum of $18: 1 \omega 7$ and odd-branched 15:0-17:0 iso and anteiso) in the profile of leaf tissues [25,26]. A similar study by Micheli [7] suggested that Parasesarma erythodactyla potentially feed on the fungi biomass living on the surface and within the leaf tissues, rather than mangrove organic matter. However, propagules, like other plant seeds, can maintain a higher $\mathrm{C} / \mathrm{N}$ ratio due to the large amount of carbon present in stored lipids and carbohydrates [15]. Moreover while tannin content decreases in decomposed $K$. candel leaves, it remains higher in mature propagules [27].

A comparison of the relative consumption rates with previous studies is complicated because of differences in the experimentally design and types of food provided in this study. However, the consumption rates of K. obovata leaves are of a similar magnitude reported for other sesarmid crabs $[3,21]$. P. bidens had high intake of both nitrogen and carbon from algae E. intestinalis, but mainly utilized nitrogen from brown leaves and carbon from propagules as indicated by the $\mathrm{C} / \mathrm{N}$ ratio of resulted faeces. According to Nordhaus and Wolff [28], the ocypodid crab Ucidens cordatus had high consumption and assimilation rates of a Rhizophora mangle diet together with algae which allow for a high intake of carbon and nitrogen. On the contrary, Sesarma messa primarily removes carbon rather than nitrogen from Rhizophora stylosa leaf litter [29].

The significant preference and consumption rate of algae over leaves by male crabs but not female when offered mixed diets (leaf + algae) is an interesting result. However, some sesarmid crabs such as Sesarma intermedia have been reported to exhibit sex-specific feeding habits [8]. The preference of algae over leaves is obvious, not only due to low $\mathrm{C} / \mathrm{N}$ ratio, but also an increasing EFAs $\omega 3 / \omega 6$ ratio in algae thalli versus leaf tissues. EFAs are important for growth, membrane transport, and the regulation of metabolism in marine animals and, in particular, a higher $\omega 3 / \omega 6$ ratio is necessary for efficient growth [30]. As was suggested by Kyomo [8] that male Sesarma intermedia are selective and females more specialized feeder, a similar situation could clarify the preference of male $P$. bidens on algae over leaves. Algal food sources could be serving as an important source of nitrogen for detritus feeding animals [10] including $P$. bidens [1]. Under Okinawa mangrove forests in particular, green macroalgae (Ulva pertusa and E. intestinalis), diatoms, and bacteria are the main contributors of sedimentary organic matter and PUFAs ( $\omega 3$ and $\omega 6$ ) instead of mangrovederived particulate organic matter during winter and spring [31]. Therefore, crabs spend most of their time cropping on surface sediments, supplementing on these nitrogenrich foods sources (Mchenga per. obser.) Present findings 
revealed $P$. bidens has a higher preference for leaves than propagules. This is contrary to the sesarmid crab Neosarmatium meinerti that showed no distinct preference between leaves and propagules under field conditions [6]. However, this crab showed less preference for mature Rhizophora mucronata propagules which could be a possible reason for our results of a low preference by $P$. bidens for mature $K$. obovata propagules.

The FAs profile of non-starved tissues revealed similar compositions when crabs were fed either under laboratory or field conditions where crabs significantly assimilate the PUFAs $18: 2 \omega 6,18: 1 \omega 3,20: 4 \omega 6,20: 5 \omega 3$, and $22: 6 \omega 3$. Depletion of $20: 4 \omega 6,20: 5 \omega 3$, and $22: 6 \omega 3$ in faeces regardless of the food types offered to crabs suggested that these EFAs have been well assimilated. However, relative increases in some of these FAs in starved tissues could be due to a biochemical strategy by crabs to conserve essential components of the biological membrane during starving periods, as was observed for juvenile Eriocheir sinensis crabs under similar circumstances [32]. The FAs profiles and $\mathrm{C} / \mathrm{N}$ ratios of resulted feaces suggested that crabs highly assimilated PUFAs when fed on algae than brown leaves or propagules. Therefore the fate of organic materials ingested by crabs may vary with food types. Faeces from an algae diet could be of less importance due to a lower amount of PUFA and nitrogen contents. However, the presence of higher percentage of bacteria in faeces (as indicated by FAs markers) could improve its nutritional status by accelerating the decomposition processes hence enriching the nitrogen contents [29]. Similarly, faeces from a propagules diet had a higher percentage of bacteria and nitrogen contents than in fresh food, indicating that the crabs which fed on propagules were unable to utilize the nitrogen present. As a result, this nitrogen remains available to bacteria [33]. Therefore, propagule faeces could be important for secondary production. Moderate amounts of MUFAs and PUFAs in faeces when crabs fed on propagules and leaves suggested that, in some circumstances, faeces could be of nutritional value to other trophic levels, especially those organisms which are unable to synthesize essential PUFA de novo [34].

\section{Conclusion}

In conclusion, the null hypothesis is rejected. Algae (E. intestinalis) had low $\mathrm{C}: \mathrm{N}$ ratios and high $\omega 3 / \omega 6$ ratios $\omega 3$ than $K$. obovata leaves and propagules, indicated algae could have a higher nutritional values and is important supplement source of nitrogen for crabs under mangrove forest. Despite of sesarmid crabs being a mangrove leaf-consumers, $P$. bidens had no distinct preference for leaves and algae but showed significantly lower consumption when fed on propagules. Similar trend was detected for the assimilation efficiency and consumption rates; however, it is sex dependents. The FAs profiles result provides a clear evaluation of the nutritional value of a given food and its assimilation by the crab. Further work should consider the use of a combined approach of FAs and $\mathrm{C} / \mathrm{N}$ ratios in determining the choice of diet by sesarmid crabs.

\section{Acknowledgments}

The authors would like to thank COE Program (University of the Ryukyus, Okinawa, Japan) and the Japan Gasoline Company-Saneyoshi Scholarship Foundation for partial support this study. They also thank Dr. Md. Moniruzzaman Saker for help with crab handling and experimental design and Ms. Kimberly K. Takagi for critically reading an earlier version of the paper.

\section{References}

[1] M. S. Islam and U. Tsuyoshi, "Feeding ecology of sesarmid crab Perisesarma bidens from mangroves of Ryukyu Islands, Japan," in Proceedings of the Ecological Society of America (ESA '05), Montreal, Canada, 2005.

[2] C. G. S. Tan and P. K. L. Ng, "An annotated checklist of mangrove brachyuran crabs from Malaysia and Singapore," Hydrobiologia, vol. 285, no. 1-3, pp. 75-84, 1994.

[3] W. D. Emmerson and L. E. McGwynnen, "Feeding and assimilation of mangrove leaves by the crab Sesarma meinerti de Man in relation to leaf-litter production in Mgazana, a warm-temperate southern African mangrove swamp," Journal of Experimental Marine Biology and Ecology, vol. 157, no. 1, pp. 41-53, 1992.

[4] S. Y. Lee, "Ecological role of grapsid crabs in mangrove ecosystems: a review," Marine and Freshwater Research, vol. 49, no. 4, pp. 335-343, 1998.

[5] T. J. Smith, "The influence of seed predators on structure and succession in tropical tidal forests," Proceeding of the Ecological Society of Australia, vol. 15, pp. 203-211, 1988.

[6] F. Dahdouh-Guebas, M. Verneirt, J. F. Tack, and N. Koedam, "Food preferences of Neosarmatium meinerti de Man (Decapoda: Sesarminae) and its possible effect on the regeneration of mangroves," Hydrobiologia, vol. 347, no. 1-3, pp. 83-89, 1997.

[7] F. Micheli, "Feeding ecology of mangrove crabs in north eastern Australia: mangrove litter consumption by Sesarma messa and Sesarma smithii," Journal of Experimental Marine Biology and Ecology, vol. 171, no. 2, pp. 165-186, 1993.

[8] J. Kyomo, "Variations in the feeding habits of males and females of the crab Sesarma intermedia," Marine Ecology Progress Series, vol. 83, no. 2-3, pp. 151-155, 1992.

[9] M. W. Skov and R. G. Hartnoll, "Paradoxical selective feeding on a low-nutrient diet: why do mangrove crabs eat leaves?" Oecologia, vol. 131, no. 1, pp. 1-7, 2002.

[10] M. Andresen and E. Kristensen, "The importance of bacteria and microalgae in the diet of the deposit-feeding polychaete Arenicola marina," Ophelia, vol. 56, no. 3, pp. 179-196, 2002.

[11] F. Dahdouh-Guebas, M. Giuggioli, A. Oluoch, M. Vannini, and S. Cannicci, "Feeding habits of non-ocypodid crabs from two mangrove forests in Kenya," Bulletin of Marine Science, vol. 64, no. 2, pp. 291-297, 1999.

[12] T. Meziane, M. C. Sanabe, and M. Tsuchiya, "Role of fiddler crabs of a subtropical intertidal flat on the fate of sedimentary fatty acids," Journal of Experimental Marine Biology and Ecology, vol. 270, no. 2, pp. 191-201, 2002.

[13] W. D. Russell-Hunter, Aquatic Productivity: An Introduction to Some Basic Aspects of Biological Oceanography and Limnology, Macmillan, New York, NY, USA, 1970.

[14] A. A. Erickson, M. Saltis, S. S. Bell, and C. J. Dawes, "Herbivore feeding preferences as measured by leaf damage and stomatal 
ingestion: a mangrove crab example," Journal of Experimental Marine Biology and Ecology, vol. 289, no. 1, pp. 123-138, 2003.

[15] S. M. Linton and P. Greenaway, "A review of feeding and nutrition of herbivorous land crabs: adaptations to low quality plant diets," Journal of Comparative Physiology B, vol. 177, no. 3, pp. 269-286, 2007.

[16] T. Meziane and M. Tsuchiya, "Fatty acids as tracers of organic matter in the sediment and food web of a mangrove/intertidal flat ecosystem, Okinawa, Japan," Marine Ecology Progress Series, vol. 200, pp. 49-57, 2000.

[17] R. J. Parkers, "Analysis of microbial communities within sediments using biomarkers," in Ecology of Microbial Communities, pp. 147-177, Cambridge University Press, 1987.

[18] D. C. Müller-Navarra, M. T. Brett, A. M. Liston, and C. R. Goldman, "A highly unsaturated fatty acid predicts carbon transfer between primary producers and consumers," Nature, vol. 403, no. 6765, pp. 74-77, 2000.

[19] R. L. Giddins, J. S. Lucus, M. J. Neilson, and G. D. Richards, "Feeding ecology of the mangrove crab Neosarmatium smithii (Crustacea: Decapoda: sesarmidae)," Marine Ecology Progress Series, vol. 33, pp. 147-155, 1986.

[20] S. Y. Lee, "Leaf choice of Sesarminae crabs, Chiromanthes bidens and C. maipoensis in a Hong Kong mangal," in The Marine Biology of the South China Sea, B. Morton, Ed., pp. 597-603, Hong Kong University Press, Hong Kong, China, 1993.

[21] T. D. Steinke, A. Rajh, and A. J. Holland, "The feeding behaviour of the red mangrove crab Sesarma meinerti de Man, 1887 (Crustacea: Decapoda: Grapsidae), and its effect on the degradation of mangrove leaf litter," South African Journal of Marine Science, vol. 13, pp. 151-160, 1993.

[22] E. G. Bligh and W. J. Dyer, "A rapid method of total lipid extraction and purification," Canadian Journal of Biochemistry and Physiology, vol. 37, no. 8, pp. 911-917, 1959.

[23] H. Yamashiro, H. Oku, H. Higa, I. Chinen, and K. Sakai, "Composition of lipids, fatty acids and sterols in Okinawan corals," Comparative Biochemistry and Physiology B, vol. 122, no. 4, pp. 397-407, 1999.

[24] A. I. Robertson, "Decomposition of mangrove leaf litter in tropical Australia," Journal of Experimental Marine Biology and Ecology, vol. 116, no. 3, pp. 235-247, 1988.

[25] R. H. Carrie, L. Mitchell, and K. D. Black, "Fatty acids in surface sediment at the Hebridean shelf edge, west of Scotland," Organic Geochemistry, vol. 29, no. 5-7, pp. 15831593, 1998.

[26] J. Chen, H. Ferris, K. M. Scow, and K. J. Graham, "Fatty acid composition and dynamics of selected fungal-feeding nematodes and fungi," Comparative Biochemistry and Physiology B, vol. 130, no. 2, pp. 135-144, 2001.

[27] Y. M. Lin, J. W. Liu, P. Xiang, P. Lin, G. F. Ye, and L. S. L. Da Sternberg, "Tannin dynamics of propagules and leaves of Kandelia candel and Bruguiera gymnorrhiza in the Jiulong River Estuary, Fujian, China," Biogeochemistry, vol. 78, no. 3, pp. 343-359, 2006.

[28] I. Nordhaus and M. Wolff, "Feeding ecology of the mangrove crab Ucides cordatus (Ocypodidae): food choice, food quality and assimilation efficiency," Marine Biology, vol. 151, no. 5, pp. 1665-1681, 2007.

[29] S. Y. Lee, "Potential trophic importance of the faecal material of the mangrove sesarmine crab Sesarma masse," Marine Ecology Progress Series, vol. 159, pp. 275-284, 1997.

[30] Y. Olsen, "Lipids and essential fatty acids in aquaculture food webs: what can freshwater ecologist learn from mariculture?" in Lipid in Freshwater Ecosystems, M. T. Arts and B. C. Wainman, Eds., pp. 161-202, Springer, New York, NY, USA, 1999.

[31] P. L. Mfilinge, T. Meziane, Z. Bachok, and M. Tsuchiya, "Litter dynamics and particulate organic matter outwelling from a subtropical mangrove in Okinawa Island, South Japan," Estuarine, Coastal and Shelf Science, vol. 63, no. 1-2, pp. 301313, 2005.

[32] X. Wen, L. Chen, Y. Ku, and K. Zhou, "Effect of feeding and lack of food on the growth, gross biochemical and fatty acid composition of juvenile crab, Eriocheir sinensis," Aquaculture, vol. 252, no. 2-4, pp. 598-607, 2006.

[33] N. Thongtham and E. Kristensen, "Carbon and nitrogen balance of leaf-eating sesarmid crabs (Neoepisesarma versicolor) offered different food sources," Estuarine, Coastal and Shelf Science, vol. 65, no. 1-2, pp. 213-222, 2005.

[34] V. Grossi, P. Cuny, S. Caradec, D. Nerini, R. Pancost, and F. Gilbert, "Impact of feeding by Arenicola marina (L.) and ageing of faecalmaterial on fatty acid distribution and bacterial community structure in marine sediments: an experimental approach," Journal of Experimental Marine Biology and Ecology, vol. 336, no. 1, pp. 54-64, 2006. 

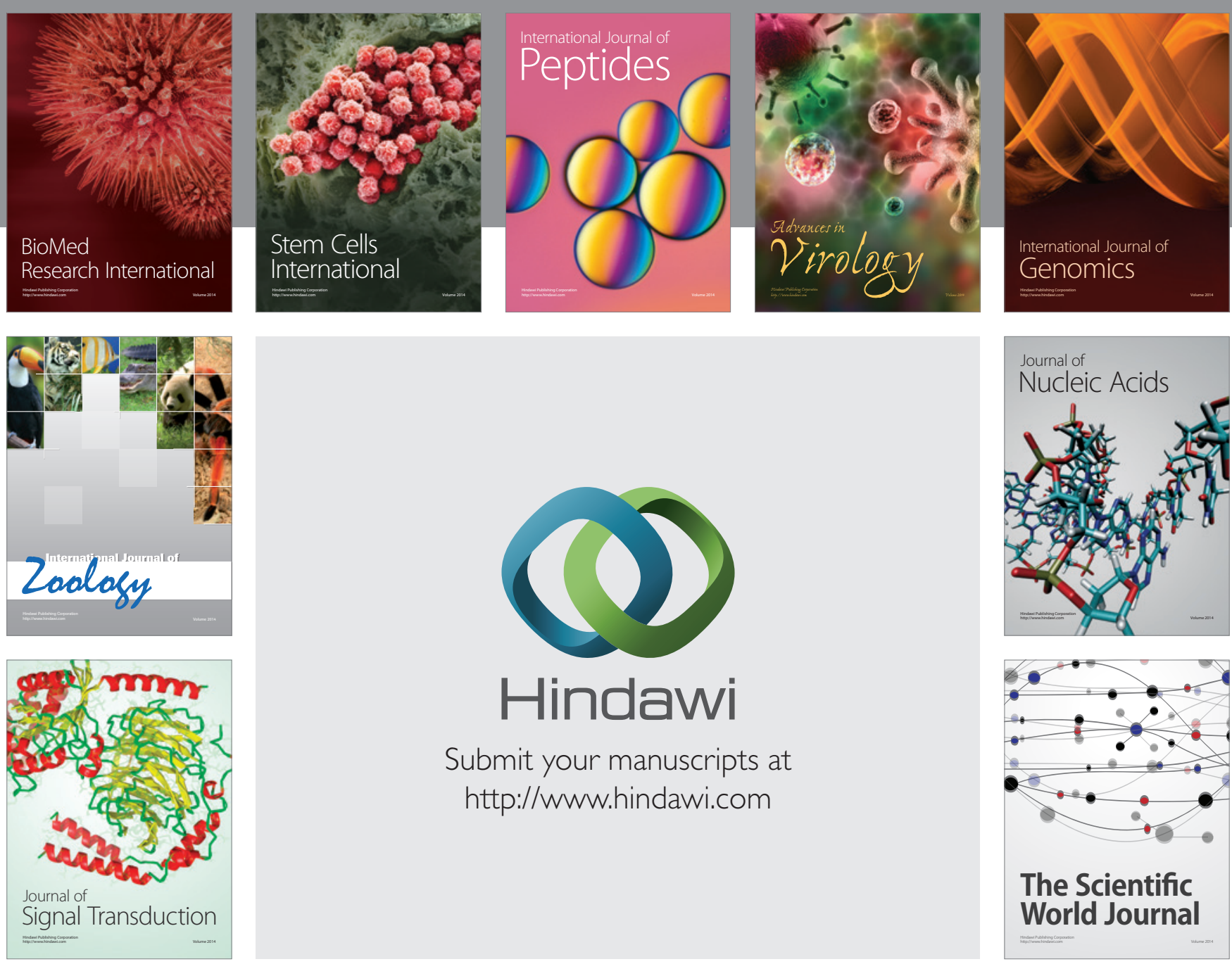

Submit your manuscripts at

http://www.hindawi.com
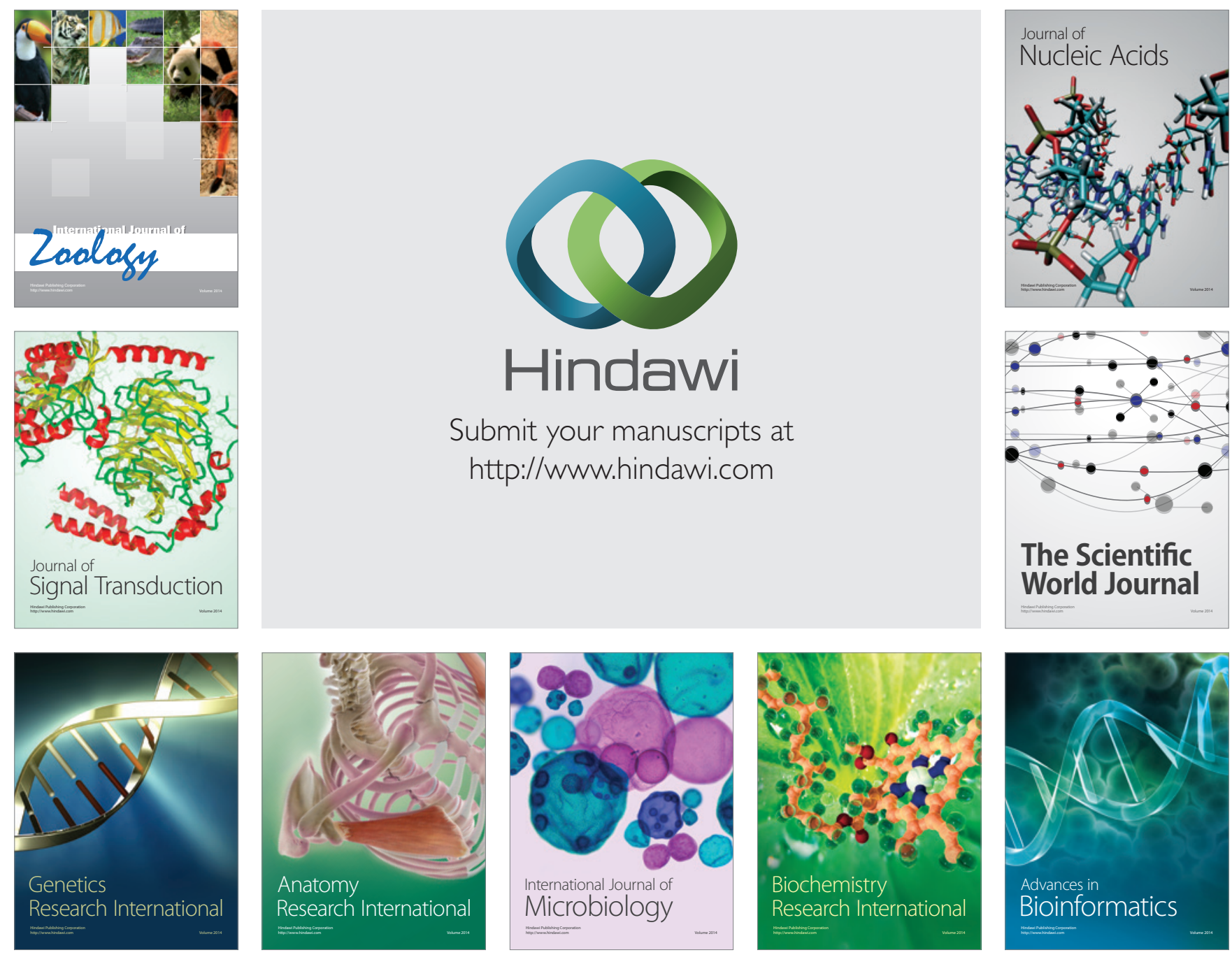

The Scientific World Journal
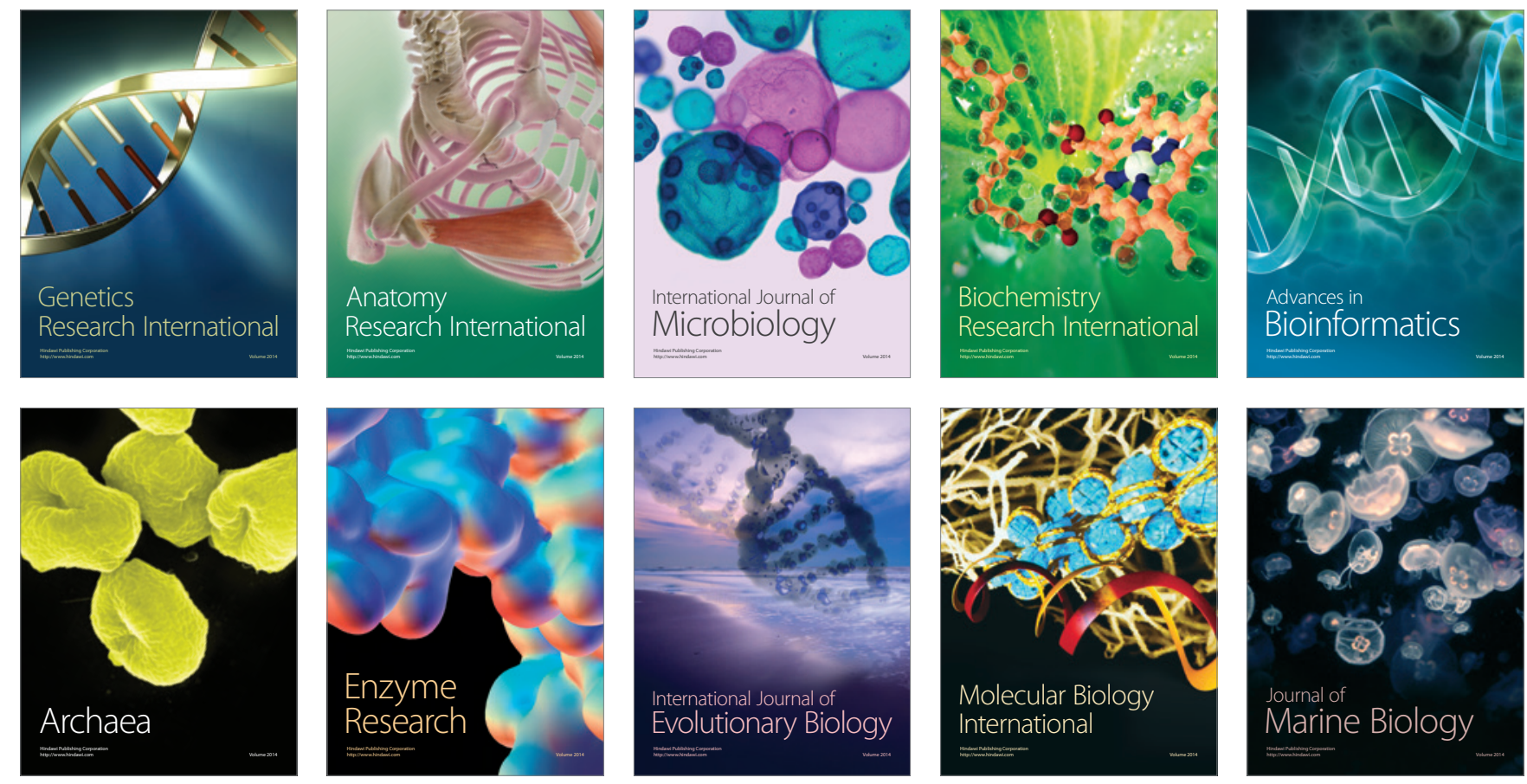